\title{
A good start at building a successful local food system in Iowa
}

\author{
Review by Susan L. Valentino* \\ Goodlife Garden
}
Review of Making Local Food Work: The Challenges and Opportunities of Today's Small Farmers, by Brandi Janssen. (2017). Published by University of Iowa Press. Available as paperback and eBook; 230 pages. Publisher's website: https://www.uipress.uiowa.edu/ books/2017-spring/making-local-food-work.htm

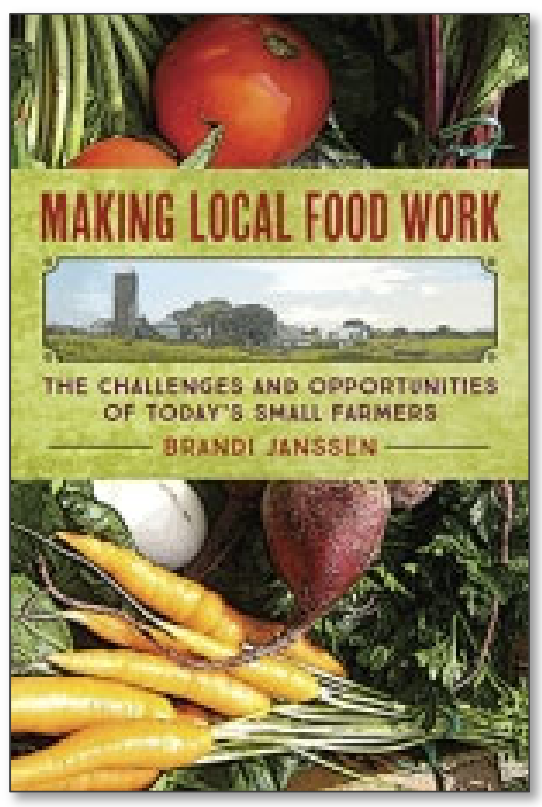

Submitted August 30, 2017 / Published online December 20, 2017

Citation: Valentino, S. (2017). A good start at building a successful local food system in Iowa [Book review]. Journal of Agriculture, Food Systems, and Community Development. Advance online publication. http://dx.doi.org/10.5304/jafscd.2017.074.013

Copyright (C) 2017 by New Leaf Associates, Inc.

$\mathrm{I}$ have been frustrated by the lack of in-depth food and nutrition information available for both teaching and research regarding the effects of food on human health; hence I have been searching for tools that I can use to help educators,

* Dr. Valentino is an education specialist in the life sciences, with concentrations in the areas of crop production, plants, disease and human health. She holds a BS in Plant Science from Cornell University and a Ph.D. in Nutrition and Immunology from Clemson University. She lives in Greensboro, South Carolina, where she runs Goodlife Garden and is working to help others provide local food security through development of similar garden businesses. She plans to launch her own educational content on YouTube soon to teach others how to better feed themselves and their families with the aim of improving health and quality of life. She can be contacted at drwellness.susan@gmail.com. students, and the general public understand the U.S. food system. Making Local Food Work falls nicely into that category. Right from the outset, author Brandi Janssen does a marvelous job of describing a wide variety of interesting and innovative approaches being used by a new generation of producers in the now fastest-growing segment of the whole food industry: local food. In this review I share my thoughts about Janssen's work from several points of view - as an academic, an educator, an advocate, and a small farmer and market vendor.

As an academic teaching in the life sciences and active in the areas of food, farming, and health, I found that choosing communities in Iowa as the subject of her attention was well considered and 
made the book more than just another accounting of the local food movement. Iowa is a good case in that local food producers and major industrial producers coexist in close proximity. This scenario lends itself nicely to Janssen's anthropological approach by providing interesting accounts of the perceptions of producers, including personal opinions of each other's agribusinesses and neighbors. For example, she skillfully addresses local conflicts and/or biases among neighbors.

As an advocate for both education about and transparency in food production, and for tactfully lifting the deliberate veil placed over much of the corporate food industry, I have been witness to much fruitless argument and accusation between the proponents of each side. The advocates of organic local food advocates often make the perfect the enemy of the good, even as corporate entities are beginning to see the profitability in organic local foods. I applaud Janssen's noncompetitive, nonconfrontational approach of presenting a well-balanced and pragmatic profile of the food production environment in Iowa.

The personal stories related in the book, whether critical of the industrial food system and its disproportionately large contribution to destruction of the environment and human health, or else embellishing the agrarian ideal of rural America, illuminate the desperate need for reason on both sides. It also, reveals how desperately people need help with understanding a very complex food system.

As an educator on how food affects health, I support any work that helps people to understand the food supply. Consumers cannot make good choices about food if they do not have adequate and accurate information regarding that food. Understanding the complexities of food production and socioeconomic influences on food availability gives consumers more power to exert over their local food systems and food environment. Janssen addresses the important aspects of food production that are necessary for the reader to gain a better understanding of the why and how of food production in the United States.

As a local food advocate, I also appreciate the comprehensive coverage of the local food movement in Iowa, a state that has long been at the core of conventional food production. Again, the selection of Iowa makes the point that for the local food movement to succeed it requires the involvement of some parts of the conventional production system. Hence, Iowa is an ideal research locality to evaluate the potential for making local food truly work.

The current food environment in the United States is the product of the history of agriculture, including slavery, and it continues to represent the moral and pollitical nature of American society. Janssen discusses the historical influence of Thomas Jefferson on some of the more unsavory aspects of the U.S. agricultural economy. She also shares some critiques of modern agriculture by early anthropologists like Walter Goldschmidt. In light of current social movements in the United States, more reflection on the aspects of the agricultural economy that formed the social and political foundation of the U.S. might have been valuable. I would also have liked to see Janssen expand upon the anthropological aspects of how food acquisition was, and still is, a powerful force in the formation of the moral character of both individuals and society.

Janssen also addresses often-overlooked factors in the local food movement, namely the higher price of local food and the unfortunate frequency of markets being located in largely affluent locations. These factors limit the capacity of the system to reach low-income customers. The discussion of the challenges to farmers markets to try to benefit everyone, not just the upper middle class, is an important one. As a vendor at a small farmers market that largely serves an affluent community of retirees and college students, I gained some useful insight from this book into how I might expand my enterprise to reach some less affluent communities through local farmer support agencies and grant programs. I also found many ideas for adding depth and new sources of income to my own agricultural business.

The chapters on more familiar components, like community supported agriculture (CSA), the green movement, and farm-to-school programs, were comprehensive and covered a wide variety of products and producers-from fruits and juicers to large herds and meat and poultry 
producers. Janssen focuses in particular on farmto-school efforts. Her discussion of the political and systemic difficulties in initiating even the simplest farm-to-school programs is spot-on. Janssen again addresses in detail how education and understanding of food production by the uninitiated is paramount to success in such endeavors.

Janssen's emphasis on the potential of local food systems elevates the prospect of making these systems stronger. It also offers hope and encouragement for small farmers, or market gardeners like myself, to make a living. To provide local food security these systems must be resilient. Janssen's presentation of the many faces of local food will serve to help the uninitiated who read Making Local Food Work to build more sustainable and reliable sources of food. 